\title{
The use of bio-efficient plant materials to optimize the fatty acid composition of poultry terrins
}

\author{
Nadezhda Popova*, Yuliya Pisklyukova, and Viktoriya Orlova \\ Department of service and restaurant business, Voronezh State University of Engineering Technologies, Voronezh, Russia
}

\begin{abstract}
The development of functional products characterized by high biological efficiency is an urgent task. The article presents the results of the development of balanced-fatty acid terrins from poultry meat. To increase the biological effectiveness of chopped products, raw materials containing omega-3 and omega-6 polyunsaturated fatty acids (PUFAs) were selected. Based on the analysis of the chemical composition of the raw material kit, the intervals for the introduction of ingredients containing biologically effective components are calculated. Their optimum amount has been experimentally established. The resulting innovative products are characterized by a balanced composition in terms of content and ratio of omega-3 and omega-6 PUFAs. In addition, the value of the indicator of biological value has increased. Developed poultry terrins can be recommended both for a wide range of consumers, and for use in diet (including low-carb diets), baby food. The developed terrines will expand the range of chopped poultry products of functional orientation.
\end{abstract}

\section{Introduction}

Currently, the health of the population in the Russian Federation is not at a sufficiently high level. Evidence of this is the high morbidity and mortality among the adult population, an increase in the number of autoimmune, endocrine, cardiovascular and other diseases. In general, low physical health indicators of all age groups are obvious. An increase in the incidence rate in the modern world is associated with improper nutrition unbalanced in basic nutrients, with a predominance of refined foods in the menu, and insufficient consumption of fruits and vegetables. As a result of all this, there is a lack of minerals, vitamins, essential amino acids and other essential components of food, including polyunsaturated fatty acids (PUFAs). The most deficient PUFAs are omega-3 fatty acids. Their content is regulated by the quantity and a certain ratio in combination with omega- 6 acids [1]. Their insufficient consumption is associated with diseases of the cardiovascular, immune and nervous systems.

The problems associated with improper nutrition cannot be solved by increasing the density of the diet, since the number of calories consumed will increase significantly, and this is unacceptable with insufficient physical activity observed in most of the population. Therefore, compliance with the principles of a healthy diet is one of the determining factors not only in the prevention, but also in the treatment of various diseases [2]. Therefore, it is necessary to search for innovative technologies and develop recipe compositions of highgrade, high-quality food products characterized by a functional orientation. The inclusion of such products in the diets for regular consumption will help to fill the lack of vital substances that are not synthesized in the human body, normalize physiological processes, increase resistance to certain diseases, and also maintain the body's overall resistance to external negative environmental factors.

\section{Experimental}

To The paper presents a study on the creation of a recipe composition for products of a functional orientation terrins from poultry meat balanced by the content of omega- 3 and omega- 6 polyunsaturated fatty acids.

Based on the analysis of literature data, the choice of the main raw material for the development of functional products, as well as sources of enrichment of terrins with polyunsaturated fatty acids, was substantiated. The next step was to determine the criteria for the enrichment of terrins in accordance with the principles of good nutrition. Next, studies were carried out to optimize the recipe composition, determine the functional and technological properties of meat and vegetable systems, organoleptic characteristics of finished products, and calculate nutritional values of enriched products.

\section{Results and discussion}

The following enrichment criteria were selected: optimization of the ratio of omega- 6 and omega-3 (5-10:1) fatty acids; the content of PUFA in the finished product is not less than 20 and not more than $50 \%$ of the daily rate; correspondence of the organoleptic characteristics of the finished product inherent to this product [1-3]

In this work, poultry meat, chicken fillet in particular, was selected as the main raw material for the production of terrines. When choosing chicken meat as the main raw material, the ratio of proteins to fats was taken into 
account. So, in chicken meat of the 1 st grade it is $1: 1.2$, for meat of the 2nd grade - 1:0.6; in carcasses of broilers of the 1st grade $-1: 0.9,2$ nd grade $-1: 0.4$ [4-6]. The content of protein and fat component also varies depending on the part of the carcass of the bird. The lowest fat content in relation to the protein is in the breast of broiler chickens (fillet) -from 0.2 to 1 . When choosing poultry meat, the composition of lipids also matters. The content of unsaturated fatty acids for the example of chicken meat of the 1st and 2nd grade is presented in Table 1. For the populations omega-3 acids are in deficit. Therefore, it is advisable to introduce fat-containing components in products from meat of chickens and broilers of the 2 nd grade without skin, while optimizing the qualitative composition of lipids, as well as the ratio of proteins and fats.

Various types of plant products were considered as ingredients enriching the developed terrins with polyunsaturated fatty acids [7-10]. The analysis and subsequent selection was carried out taking into account the content of omega- 3 acids; ratios of omega- 6 and omega-3 PUFA; the effect of the introduced biologically effective ingredient on the organoleptic properties of the product.

The most optimal biologically effective ingredients for introducing terrins into recipes are cedar nuts cake (CNC) and flax seeds (FS) [7-10]. Their fatty acid composition varies significantly (Table 2). However, the joint use of terrins in the formulation will allow, without changing the organoleptic indicators, to optimize the fatty acid composition of chopped products, enriching them with deficient omega-3 acids.

When choosing the optimal concentration of the introduced ingredients, the daily consumption rates of omega-3 and omega-6 PUFAs, which are 0.8-1.6 g/day and 8-10 g/day, respectively, were taken into account [1]. The recommended ratio of acids of the omega- 6 : omega- 3 families, which is 5-10:1, was taken into account. Given that the amount of enrichment component introduced in the finished product should cover at least 20 and not more than $50 \%$ of the daily requirement for this substance, the range of variation of the added additive in terrins was: cedar nut cake weight from 1 to $2.5 \%$, flax seed from 0.25 to $1.25 \%$ of the main raw material weight. To clarify the number of introduced plant biocomponents into the developed dish, an analysis was made of the functionaltechnological properties (FTP) - water-retaining (WRP) and fat-holding (FHP) abilities. Additionally, organoleptic evaluation of samples with different amounts of bioefficient plant components was performed. Terrins prepared without the addition of PUFA sources were used as a control sample. The results are shown in Table 3.

An analysis of the functional-technological properties of meat and vegetable systems showed that the WRP and FHP reach their maximum values in meat and vegetable systems at number 2 and their values practically do not differ from the control. With a further increase in the input of bio-efficient plant components into the chopped mass, the processes of binding and retention of moisture and fat deteriorate. Also noted negative changes in the taste and smell of the finished products, indicated in Table 3, which is unacceptable.

Based on the studies, it was experimentally established that the optimal amount of biologically effective components introduced is $1.5 \%$ for cedar nuts cake and $0.5 \%$ for flax seeds, based on the weight of the main raw materials, which amounts to $2 \%$.

To assess the quality indicators of finished products, their nutritional value was calculated. The chemical composition of the developed products is presented in Table 4.

From the values presented in the tables it can be seen that the developed products have a balanced chemical composition. Terrins are characterized by increased biological effectiveness, because in terms of content and ratio of omega- 3 and omega- 6 PUFAs, they meet established criteria. Due to the introduction of cedar nuts cake in the recipe, the amino acid composition of the finished products has changed. The biological value of the developed terrins increased by $2.6 \%$ compared with the control sample and amounted to $88.2 \%$.

The composition of the fatty acids of the resulting products is presented in Table 5 .

Table 1. Fat and oxygen composition of chicken meat

\begin{tabular}{|c|c|c|}
\hline \multirow{2}{*}{ Name of indicator } & \multicolumn{2}{|c|}{ Content, g/100 g } \\
\cline { 2 - 3 } & $\begin{array}{c}\text { 1st grade } \\
\text { chickens }\end{array}$ & $\begin{array}{c}\text { 2nd grade } \\
\text { chickens }\end{array}$ \\
\hline $\begin{array}{c}\text { The amount of PUFA, } \\
\text { including: }\end{array}$ & 3.17 & 1.64 \\
\hline Omega-3 & 0.17 & 0.07 \\
\hline Omega-6 & 2.96 & 1.47 \\
\hline Omega-6/omega-3 ratio & $17.4: 1$ & $23.4: 1$ \\
\hline
\end{tabular}

Table 2. Fatty acid composition of pufa sources

\begin{tabular}{|c|c|c|}
\hline \multirow{2}{*}{ Name of indicator } & \multicolumn{2}{|c|}{ Content, g/100 g } \\
\cline { 2 - 3 } & cedar nut cake & flax seed \\
\hline $\begin{array}{c}\text { The amount of PUFA, } \\
\text { including: }\end{array}$ & 21.2 & 28.7 \\
\hline Omega-3 & 7.6 & 22.8 \\
\hline Omega-6 & 13.6 & 5.9 \\
\hline $\begin{array}{c}\text { Omega-6/omega-3 } \\
\text { ratio }\end{array}$ & $1.8: 1$ & $0.26: 1$ \\
\hline
\end{tabular}

Table 3. Functional-technological properties of meat and vegetable systems and organoleptic indicators of finished products

\begin{tabular}{|c|c|c|c|c|c|}
\hline \multirow[t]{2}{*}{$\begin{array}{l}\text { Object of } \\
\text { study }\end{array}$} & \multicolumn{2}{|c|}{\begin{tabular}{|c|} 
Content to \\
the mass of \\
the main raw \\
material, \%
\end{tabular}} & \multirow[t]{2}{*}{ WRP, \% } & \multirow[t]{2}{*}{ FHP, \% } & \multirow[t]{2}{*}{$\begin{array}{l}\text { Organoleptic } \\
\text { characteristics of } \\
\text { the finished } \\
\text { product }\end{array}$} \\
\hline & CNC & FS & & & \\
\hline $\begin{array}{l}\text { Control } \\
\text { sample }\end{array}$ & - & - & 70.2 & 71.9 & $\begin{array}{l}\text { Specific to this } \\
\text { product }\end{array}$ \\
\hline №1 & 1 & 0.25 & 69.3 & 70.2 & $\begin{array}{c}\text { Extraneous smacks } \\
\text { and odors are not } \\
\text { observed }\end{array}$ \\
\hline №2 & 1.5 & 0.5 & 70.4 & 71.6 & $\begin{array}{c}\text { Extraneous smacks } \\
\text { and odors are not } \\
\text { observed }\end{array}$ \\
\hline №3 & 2 & 0.75 & 69.2 & 68.5 & $\begin{array}{l}\text { The consistency is } \\
\text { denser, faint taste of } \\
\text { CNC }\end{array}$ \\
\hline №4 & 2.5 & 1.25 & 68.9 & 69.1 & $\begin{array}{c}\text { Sweet taste of CNC } \\
\text { is observed }\end{array}$ \\
\hline
\end{tabular}


Table 4. Chemical composition and energy value of the developed terrins (per $100 \mathrm{~g}$ of the product)

\begin{tabular}{|c|c|c|c|c|c|c|c|}
\hline $\begin{array}{c}\text { Name of } \\
\text { indicator }\end{array}$ & $\begin{array}{c}\text { Indicator } \\
\text { value }\end{array}$ & $\begin{array}{c}\text { Name of } \\
\text { indicator }\end{array}$ & $\begin{array}{c}\text { Indicator } \\
\text { value }\end{array}$ & $\begin{array}{c}\text { Name of } \\
\text { indicator }\end{array}$ & $\begin{array}{c}\text { Indicator } \\
\text { value }\end{array}$ & $\begin{array}{c}\text { Name of } \\
\text { indicator }\end{array}$ & $\begin{array}{c}\text { Indicator } \\
\text { value }\end{array}$ \\
\hline Proteins, g & 24.4 & Vitamin B1, mg & 0.08 & Vitamin $\mathrm{E}, \mathrm{mg}$ & 0.2 & $\mathrm{~K}, \mathrm{mg}$ & 350.4 \\
\hline Fats, g & 2.4 & Vitamin B2, mg & 0.07 & Vitamin H, mg & 0.01 & $\mathrm{P}, \mathrm{mg}$ & 196.1 \\
\hline $\begin{array}{c}\text { Carbohydrates, } \\
\mathrm{g}\end{array}$ & 1.8 & Vitamin B3, mg & 0.04 & Vitamin PP, mg & 11.1 & $\mathrm{Zn}, \mathrm{mg}$ & 1.5 \\
\hline Ash, mg & 2.1 & Vitamin B6, mg & 0.02 & \multicolumn{2}{|c|}{ Minerals } & $\mathrm{Mg}, \mathrm{mg}$ & 37.8 \\
\hline Fiber mg & 0.6 & Vitamin B9, mg & 0.03 & $\mathrm{Fe}, \mathrm{mg}$ & 1.6 & $\mathrm{Mn}, \mathrm{mg}$ & 0.3 \\
\hline Calories, kcal & 126 & Vitamin A, mg & 0.02 & $\mathrm{Ca}, \mathrm{mg}$ & 13.4 & $\mathrm{I}, \mathrm{mg}$ & 0.04 \\
\hline \multicolumn{2}{|c|}{ Vitamins } & Vitamin C, mg & 1.04 & $\mathrm{Na}, \mathrm{mg}$ & 354.9 & $\mathrm{~S}, \mathrm{mg}$ & 4.07 \\
\hline
\end{tabular}

Table 5. Fatty acid composition of terrins

\begin{tabular}{|c|c|c|}
\hline Name of indicator & $\begin{array}{c}\text { Indicator } \\
\text { value }\end{array}$ & $\begin{array}{c}\text { Daily requirement } \\
\text { satisfaction, \% }\end{array}$ \\
\hline $\begin{array}{c}\text { The amount of PUFA } \\
\text { per 100 g of product } \\
\text { including: }\end{array}$ & 2.5 & $25-35$ \\
\hline Omega-3 & 0.4 & $25-50$ \\
\hline Omega-6 & 2.1 & $21-26$ \\
\hline $\begin{array}{c}\text { Omega-6/omega-3 } \\
\text { ratio }\end{array}$ & $5.3: 1$ & - \\
\hline
\end{tabular}

\section{Conclusion}

Studies have proved the feasibility of creating terrins with a balanced fatty acid composition from poultry meat by introducing cedar nuts cake and flax seeds into the recipe. Their joint use allows to obtain products of high nutritional value, which are recommended for inclusion in the diets of healthy nutrition of various population groups. It is advisable to further expand the assortment of various functional foods using oilseed raw materials and products of its processing to enrich the diets of modern man with irreplaceable polyunsaturated fatty acids.

\section{References}

1. Norms of physiological requirements for energy and nutrients for various groups of the population of the Russian Federation: guidelines 2.3.1.2432-08 from 18.12.2008. Moscow (2008)

2. N.N. Popova, The basics of good nutrition. Textbook (VSUET, Voronezh, 2013)

3. N.N. Popova and L.I. Stolbovskikh, Service in Russia and abroad, 5(43), 30-37 (2013)

4. L.A. Donskova, N.M. Belyaev, and N.V. Leiberova, Food Industry, 1, 5-9 (2018).

5. GOST 31962-2013. Chicken meat (carcasses of hens, chickens, broiler chickens and parts thereof). Technical conditions, Moscow: Standartinform (2016).

6. V.A. Gonotsky, Y.N. Krasyukov, and V.I. Dubrovskaya, Poultry and poultry products, 1, 23-26 (2013).

7. N.N. Popova, A.V. Mashneva, and V.A. Orlova, Polyunsaturated fatty acids in the production of meat products in Materials of the VI International Scientific and Practical Conference: "Food Security: Scientific, Personnel and Information Support", (VSUET, Voronezh, 2019).

8. N.N. Popova and Y.N. Pisklyukova, Voronezh: VSUET, 91-93 (2019).

9. E.S. Sofronova, Bulletin of the Institute of Nuclear Power Engineering, 8. 21-29 (2012).

10. I.S. Patrakova, Technology of functional meat products: teaching materials for students (KemTIPP, Kemerovo, 2007). 